\title{
Unleashing Market Forces in Legal Education and the Legal Profession
}

\author{
Deborah Jones Merritt* and Daniel C. MerritT
}

Law schools compete obsessively. They vie for students with the highest LSAT scores and grade-point averages. They bid for the most widely cited professors. They sponsor conferences and programs to capture public attention. Most of all, they labor to improve their ranking in U.S. News and World Report, to outshine the schools just above them and stay ahead of the ones just below. In the eyes of many law professors, legal education is a highly competitive market.

As Brian Tamanaha explains in his groundbreaking book Failing Law Schools, ${ }^{1}$ this competition does little to benefit law students, practitioners, or clients of the legal system. Law school tuition has skyrocketed, with many students taking on more debt than they can reasonably repay. ${ }^{2}$ Employers complain that, despite this expensive education, graduates lack basic practice skills. ${ }^{3}$ Median starting salaries for law school graduates have dropped by twenty percent in just two years, ${ }^{4}$ while jobs themselves have become much more

* John Deaver Drinko/Baker \& Hostetler Chair in Law, Moritz College of Law, The Ohio State University. We thank Paul Campos, Paul Horwitz, Andrew Merritt, Brian Tamanaha, and Ben Trachtenberg for their very helpful comments on earlier drafts. (C) 2013, Deborah Jones Merritt and Daniel C. Merritt.

1. See generally, Brian Z. TAMANaha, FaIling Law Schools (2012).

2. Id. at 107-25.

3. See, e.g., Ashby Jones, Who Should Foot the Bill for the "Worthless" Young Associates?, WALL ST. J. L. BLog (Apr. 13, 2010, 11:03 AM), http://blogs.wsj.com/law/2010/04/13/who-should-foot-the-bill-for-theworthless-young-associates/ (reporting a general counsel's widely reported comment that first- and second-year associates are "worthless"); Ashby Jones, Legal Heavies Tackle the First-Year Associate Dilemma, WALL ST. J. L. BLOG (Dec. 9, 2009, 4:02 PM), http://blogs.wsj.com/law/2009/12/09/legal-heavies-tackle-the-first-yearassociate-dilemma/ (describing earlier comments on the same issue).

4. NALP, the national association for legal career professionals, reports that the median salary for 2009 law graduates was $\$ 72,000$ nine months after graduation. The median salary for 2011 graduates, measured at the same mark, was $\$ 60,000$. Median Private Practice Starting Salaries for the Class of 2011 Plunge as Private Practice Jobs Continue to Erode, NALP (July 12, 2012), http://www.nalp.org/classof2011_salpressrel. NALP reports the drop as $17 \%$, but that calculation disregards inflation. If 2009 salaries had kept pace with inflation, the median 2011 salary would have been $\$ 75,491$. CPI Inflation Calculator, BUREAU OF LABOR STATISTICS, http://data.bls.gov/cgi-bin/cpicalc.pl?cost $1=72000 \&$ yearl $=2009 \&$ year $2=2011$ (last visited March 16, 2013). The drop to $\$ 60,000$ represents a $20.5 \%$ decrease in real dollars.

Discouraging as these numbers already are, they overstate the salaries earned by many graduates. As Professor Tamanaha and others have noted, entry-level salaries display a sharply bimodal distribution, TAMANAHA, supra note 1, at 112-14, and reported salaries skew toward the high end of the distribution, id. at 146-54. In 2011, NALP reported salaries for only 18,630 graduates, just $41.9 \%$ of all graduates that year. Class of 2011 Summary Report, NALP, http://www.nalp.org/uploads/NatlSummChart_Classof2011.pdf (last visited Mar. 16, 2013). For further discussion of salaries earned by recent graduates, and of distortion in the reported figures, see Paul Campos, The Crisis of the American Law School, 46 U. MICH. J.L. REFORM 177 (Fall 2012). 
elusive. ${ }^{5}$ At the same time that law graduates scramble to find jobs, a large number of citizens struggle to find affordable legal services. ${ }^{6}$

How could market forces go so awry? If law schools compete so aggressively, why doesn't the market produce tuition that better matches earning potential? Why can't clients find lawyers to serve them? Why don't schools reduce class size when graduates can't find jobs? Why don't schools differentiate their training to serve different markets? Professor Tamanaha cogently outlines two answers. First, legal educators have used the American Bar Association (ABA) to secure accreditation standards that increase faculty salaries, reduce teaching loads, and otherwise serve institutional interests. Sheltered by these standards, law schools ward off cheaper competitors-while attributing their high tuition to the necessary costs of quality education.

Second, law schools rely upon a deep well of federal loan dollars. Law students don't have to pay for their schooling, at least not up front. The federal government will disburse loans covering tuition and living costs to any student enrolled in an accredited law school. Law schools need only admit willing students, set tuition, and collect the loan money. The students and government deal with the painful task of repayment, long after the student has departed campus.

These two factors-partial capture of the accreditation body and guaranteed government loans-assure that law schools do not compete in the type of market that most businesses face. Rather than battling in an open field, law schools joust in the courtyard of a heavily walled castle. The schools compete with one another, not against open market forces. To cure this problem, Professor Tamanaha proposes loosening the ABA's accreditation standards and restricting the flow of federal loan dollars. ${ }^{7}$

We agree with both Professor Tamanaha's diagnosis and his prescription. If we are going to protect students, new lawyers, employers, clients, and the legal system itself, we need to unleash market forces in legal education. This will require changing accreditation standards, altering the process for setting those standards, and limiting the government's blank-check support of legal education. But we need to go even further. In this essay, we build upon Professor

5. Tamanaha, supra note 1, at 114-18. The most recent figure reported by Professor Tamanaha is for the class of $2009 ; 62.5 \%$ of those graduates obtained jobs requiring bar passage. That percentage has continued to drop. In 2010,59.9\% of graduates secured jobs requiring bar passage; the following year, just $56.0 \%$ did. Class of 2011 Has Lowest Employment Rate Since Class of 1994, NALP (July 2012), http://www.nalp.org/ 0712research (note that to determine the percentage of all graduates employed in jobs requiring bar admission, it is necessary to multiply the percentage employed by the percentage employed in jobs requiring bar admission). See also Campos, supra note 4, at 197-205 (offering further detail on jobs obtained by recent law graduates).

6. TAMANAHA, supra note 1, at 170 ("Perversely, the United States has an oversupply of law graduates at the same time that a significant proportion of the populace ... go without legal assistance.").

7. TAMANAHA, supra note 1 , at $172-81$. 
Tamanaha's analysis by highlighting an even more important force that drives the spiraling cost of legal education: trade restraints on law practice. To reduce the unbearable price of legal education, improve the quality of that training, and deliver affordable services to clients, we need to unleash market forces in law practice itself.

\section{THE LAWYER GUILD}

Professor Tamanaha succinctly outlines the anti-competitive effects of ABA accreditation standards for law schools. Early in the twentieth century, elite schools persuaded the ABA to mandate three years of full-time study to earn a law degree from an accredited school. ${ }^{8}$ Building on that success, schools used the accreditation process to establish tenure protections, ${ }^{9}$ support higher faculty salaries, ${ }^{10}$ lower teaching loads, ${ }^{11}$ and obtain other benefits for full-time faculty. Law schools, in sum, created a legal educators' guild to maintain artificially high benefits for members of that guild. ${ }^{12}$

But the law school guild operates within a broader one: the guild of the legal profession. Every state maintains strict rules against the unauthorized practice of law. ${ }^{13}$ Bar associations and individual lawyers vigorously enforce those rules, using lawsuits and other measures to inhibit legal work by non-lawyers. ${ }^{14}$ These trade restrictions play a key role in propelling the price of legal education by dividing those who are "authorized" to practice law from all others.

Observers sometimes scoff at the notion that the legal profession is a restricted guild exacting economic rents from clients. ${ }^{15}$ How can that possibly be true when there is such a glut of lawyers? These critics overlook the fact that a guild can allocate its excess profit to just a portion of its members. ${ }^{16}$ The remaining guild members, who lack access to the cartel's profits, will compete for small rewards

8. Id. at $20-27$.

9. Id. at 28-36. As Professor Tamanaha outlines in this chapter, a recent proposal would have diluted tenure requirements in ABA accreditation standards. This proposal, predictably, elicited widespread condemnation from schools, faculty organizations, and individual faculty.

10. Id. at $11-12,14-16,196$ n. 16 .

11. Id. at $11-12,52-53$.

12. For further description of the manner in which law schools used the accreditation process to secure faculty benefits, see George B. Shepherd, Cartels and Controls in Legal Training, 45 ANTTTRUST Bull. 438, 445-50 (2000).

13. See generally Restatement (ThIRD) of THE LAW Governing LaWyers § 4 (2011); Deborah L. Rhode, Policing the Professional Monopoly: A Constitutional and Empirical Analysis of Unauthorized Practice Prohibitions, 34 STAN. L. REv. 1, 11-12 (1981).

14. See, e.g., Deborah Rhode, Access to Justice: Connecting Principles to Practice, 17 Geo. J. Legal EtHICS 369, 401, 405-11 (2004); Rhode, supra note 13.

15. Economic rents are "profit[s] earned in excess of the return a perfectly competitive market would yield." Illinois v. Panhandle E. Pipe Line Co., 935 F.2d 1469, 1481 (7th Cir. 1991).

16. See Richard A. Posner, The Material Basis of Jurisprudence, 69 IND. L.J. 1, 17 (Winter 1993) ("[S]o long as the number of lawyers is limited" to some extent, "some lawyers, at least, will enjoy monopoly returns."). 
or leave the profession. This creates the appearance of an oversupply of lawyers. As we explain further below, the apparent "glut" can even support the guild's economic power.

How does the expensive system of legal education, so evocatively described by Professor Tamanaha, serve the larger guild? Lawyers, like other professional guild members, face an ongoing challenge. They want to restrict entry to protect profits, but they must allow enough new entrants to minimally satisfy consumers; otherwise, society will overturn the guild's monopoly. Furthermore, professional guilds perform complex services that take time to master. These guilds cannot admit new members only as old ones die off. Instead, a professional guild must admit and train new entrants on a regular basis. ${ }^{17}$

There are three principal ways that guilds address this conundrum. First, some guilds strictly limit entry at the outset of professional training. In addition to achieving the guild's aim in the most direct way, this approach allows the guild to focus training on a small number of new entrants. The guild can tout this benefit to the public in order to justify both the limited entry and the guild's excess profits. "Our training," this approach suggests, "is so special and so expensive that we can offer it to only a very limited number of people." For the new entrants, this is the happiest path: Once admitted, they are virtually certain to share eventually in the guild's profits. As long as the guild admits sufficient entrants to minimally serve consumers, it can maintain its dominance.

Second, guilds can restrict entry by making the path to full guild membership very long, arduous, and expensive. A large number of hopefuls may start down this path, each individually confident in success. ${ }^{18}$ But as time goes on, some entrants will not be able to bear the ongoing investments of time and expense; they will fall by the wayside. Others will realize that, although they have the energy to continue, the pay-off is too remote. Rather than continue to invest heavily in the guild profession, they will switch to a field that offers more immediate reward. Still other hopefuls, witnessing the long path to guild entry, will avoid the profession entirely. In all of these ways, long entry paths effectively pare the number of people who ultimately share in the guild's profits. ${ }^{19}$

17. See id. at 10 ("[A] guild must make provisions for its continuation into the indefinite future. Even if the guild's members have no concern about its flourishing after they are dead, the guild cannot hope to retain its privileged status ... if it does not hold out reasonable assurances of being able to supply the [society's] ... needs for the indefinite future.").

18. Two related biases, one based on self-enhancement and the other on optimism, stoke this confidence. See, e.g., Carlo Caponecchia, It Won't Happen to Me: An Investigation of Optimism Bias in Occupational Health and Safety, 40 J. APplied Soc. Psychol. 601 (2010); David Dunning, et al., Flawed Self-Assessment: Implications for Health, Education, and the Workplace, 5 PSYCHOL. SCI. PUB. INTEREST 69 (2004); Gregory S. Preuss \& Mark D. Alicke, Everybody Loves Me: Self-Evaluations and Metaperceptions of Dating Popularity, 35 Personality \& Soc. Psychol. Bull. 937 (2009).

19. Pre-industrial craft guilds and modern professions have both relied upon this technique. See, e.g., Sheilagh Ogilvie, Guilds, Efficiency, and Social Capital: Evidence from German Proto-Industry, 58 EcoN. HIST. 
Strenuous entry paths also suggest to the public that the guild practices a very difficult profession, one that requires many years and expensive training to master. Successful guild members can point to those factors to justify their eventual profits. ${ }^{20}$ Long, difficult, and expensive training can also increase the public's reliance on the guild; consumers may fear that unregulated practitioners, lacking this extensive training, would provide defective services.

Despite these advantages for the guild, this second approach can be quite damaging for new entrants. Newcomers almost certainly invest more time and money in their training than is necessary; the guild has artificially increased training demands to reduce entry. Aspirants who leave the profession before receiving any guild profits suffer even more: they may lose the full value of their investment.

The final way that professional guilds can limit entry is through intramural competitions. Under this approach, the guild allows many hopefuls to begin training, and even to invest substantially in that training. Ultimately, however, the guild permits only a small number of entrants to reach the highest levels of guild status and profit-making. Aspirants advance only when they "make the cut" in successive competitions. These competitive hurdles, like the lengthy training paths in the previous approach, signal consumers that the successful guild members have superior skills: they are the ones who have bested all other competitors. This perception, in turn, helps justify the guild's artificially high prices. $^{21}$

This final approach is particularly costly for many guild entrants. Newcomers may invest heavily in their training, only to be knocked out of the running. When they fail to achieve guild success, these entrants may blame themselves rather than the guild's structure. Even when entrants succeed, they may remain wary of other guild members. Ongoing competition can diminish collegiality in the guild.

These three approaches are not mutually exclusive; guilds can adopt a mixture of styles. The American medical profession relies primarily on the first approach, tightly limiting the number of students accepted into medical school and residencies each year. ${ }^{22}$ But the profession also draws upon the second path,

REv. 286, 307-08 (2004) (noting that long apprenticeships and entry fees helped pre-industrial guilds restrict entry); Posner, supra note 17, at 6 ("The most characteristic ... professional restriction today is a requirement of protracted formal education including some, and sometimes a lot of, specialized university-type education, plus proof of intellectual competence demonstrated by passing a demanding written examination.").

20. See Posner, supra note 16, at 11 ("[T]he longer the period of apprenticeship the more plausibly can the guild represent to the public that making a high-quality product is a task requiring unusual skill that can be acquired only by lengthy training.").

21. Free markets, of course, also produce competition; some businesses prosper while others fail. Guild tournaments differ from market competition because the guild determines the rules and can artificially limit the number of winners. As we explain below in the context of legal services, these guild-controlled competitions do little to benefit consumers. See infra text following note 51.

22. See, e.g., Milton Friedman, Capitalism and Freedom 150-51 (1962); David Blumenthal, New Steam from an Old Cauldron-The Physician-Supply Debate, 350 NEw ENG. J. MED. 1780 (2004). 
creating a long, arduous, and expensive path to full licensure. ${ }^{23}$ No one knows if doctors need as much training as they currently receive-or if the training needs to cost as much as it does. Successful guild members set the standards, and aspiring doctors have no choice but to meet them.

The United States legal profession has not been able to limit entry as overtly as the medical profession has. The American public wants doctors to train at top hospitals with cutting-edge technologies. Physicians, the AMA, and the federal government all point to the expense of those facilities as limiting the pipeline for doctors. ${ }^{24}$ Legal education does not require that type of capital investment; nor does it offer other rationales for strict entry barriers.

Antitrust laws further limit the legal profession's ability to restrict entry. As Professor Tamanaha recounts, the Department of Justice sued the ABA for using its accreditation standards to restrict creation of low-cost law schools. ${ }^{25}$ If the $\mathrm{ABA}$ attempted to limit the number of law school seats even more openly, the Department surely would intervene. ${ }^{26}$

The legal profession, however, quite effectively employs the second and third approaches to guild maintenance. The profession has designed a long, arduous, and expensive route to licensure. It has also created a highly competitive system in which only a small number of contestants achieve the positions that deliver the highest economic rents. We summarize these features of the legal profession below, and then briefly outline their costs to prospective lawyers, clients who need legal services, and the profession itself.

\section{A. THE LONG PATH TO BECOMING A LAWYER}

Aspiring attorneys travel a long road from high school graduation to bar admission, one that includes seven years of higher education and a bar examination. To secure a steady legal job, they often must serve a variety of summer or part-time internships while in school; many of these internships are unpaid. Increasingly, prospective lawyers undertake low-paid fellowships or other temporary positions after graduation to further enhance their employabil-

23. Friedman, supra note 22, at 151.

24. See, e.g., Blumenthal, supra note 22 . Government programs help support medical residency programs, giving the government a role in determining the number of training slots available for doctors.

25. TAMANAHA, supra note 1, at 11-19.

26. Conversely, the medical profession has been able to deflect antitrust challenges. In 2002 , for example, a group of medical students challenged the system that matches students to medical residencies as anticompetitive. See Adam Liptak, Medical Students Sue Over Residency System, N.Y. Times (May 7, 2002), available at http:/www.nytimes.com/2002/05/07/us/medical-students-sue-over-residency-system.html?page wanted $=$ all\&src $=$ pm. The court dismissed the lawsuit after Congress amended the antitrust laws to confirm that medical residencies do not violate those laws. 15 U.S.C. \& 37(b) (2004); Sara Robinson, Antitrust Suit Over Medical Residency System Is Dismissed, N.Y.TImEs (Aug. 14, 2004), available at http://www.nytimes.com/2004/ 08/14/us/antiturest-lawsuit-over-medical-residency-system-is-dismissed.html. 
ity. ${ }^{27}$ Even after obtaining a "permanent" job, the graduate has not fully penetrated the profession. She will invest several more years working as a subordinate lawyer, often changing jobs several times. ${ }^{28} \mathrm{~A}$ measure of professional autonomy, stability, and economic reward will come only after many more years in the workforce.

Aspiring lawyers do not simply clock time on this path; every step requires intense intellectual and emotional effort. Most students admitted to law school have earned top academic records from well-regarded colleges. They have also obtained high scores on the LSAT, often after extensive test preparation. Law school classes themselves are challenging. At the same time that they complete those classes, many students participate in a demanding schedule of law journal or moot court activities, other extracurricular organizations, and workplace experiences. These activities are important resume builders in today's job market. After graduation, potential lawyers face a grueling bar exam; state supreme courts have repeatedly increased the length and difficulty of that exam..$^{29}$ Once in practice, new lawyers endure long hours, demanding (and often tedious) work, and uncertain futures.

Finally, this path is shockingly expensive. Professor Tamanaha details the dramatic rise in law school tuition between 1985 and 2009. In constant dollars, the cost of a private law school education more than doubled during those years; the price of attending a public school more than quadrupled. ${ }^{30}$ And law schools have not slowed the rate of tuition increases since Professor Tamanaha finished gathering his data. Private schools averaged five percent tuition increases in both 2010 and 2011; public schools raised tuition for in-state students by ten percent the first year and nine percent the next. ${ }^{31}$ During these same years, job openings

27. Law schools themselves are funding many of these fellowships. See New Research on Law School Funded Positions for Law School Graduates, NALP BuLl. (Sept. 2012), available at http://www.nalp.org/ sept12research_lsfunded. Graduates take these temporary, low-paid positions with the hope that they may lead to higher paying permanent jobs.

28. See Ronit Dinovitzer, et al., After the JD II: Second Results from a National Study of Legal CAREERS 54 (2009) (finding that within three years of law school graduation, more than a third of lawyers had changed jobs at least once; over the next four years, almost two-thirds did so).

29. See Deborah J. Merritt, et al., Raising the Bar: A Social Science Critique of Recent Increases to Passing Scores on the Bar Exam, 69 U. CIN. L. REv. 929 (2001) (examining changes made to bar passing scores during the 1990s); Shepherd, supra note 12, at 444 (noting that states lowered bar exam pass rates in the 1920s and 1930s to reduce "overcrowding" in the profession).

30. Tamanaha, supra note 1, at 108-09. Paul Campos places these numbers in context by comparing them to median household income, which has been stagnant for the last forty years. Professor Campos concludes, "A legal education, which a generation ago was easily within the financial reach of the American middle class, and was to some extent a realistic career option even for people of more modest socio-economic backgrounds, has now become an enormously expensive investment." Campos, supra note 4, at 183.

31. Law School Tuition, 1985-2011, AMERICAN BAR AsSOCIATION, http://www.americanbar.org/content/dam/ aba/administrative/legal_education_and_admissions_to_the_bar/statistics/ls_tuition.authcheckdam.pdf (last visited Apr. 25, 2013). Schools have offset some of these increases with enhanced scholarship aid but, as graduates' heavy loan burdens suggest, scholarships have not kept pace with tuition. See infra notes 37-40 and accompanying text. In addition, most law schools tie scholarships to LSAT scores and undergraduate GPAs, 
and salaries plummeted for new law school graduates. ${ }^{32}$

In addition to paying high tuition, law students incur other financial burdens. Taking three years out of the job market imposes heavy opportunity costs. ${ }^{33}$ Many students eschew all paying work during their first year, devoting their full attention to studies and maximizing class rank. Even during their second and third years, ABA rules prohibit students from working more than twenty hours a week while enrolled as full-time students. ${ }^{34}$ On top of these costs, students pay for LSAT preparation courses, living expenses during law school, job-hunting costs, bar admission fees, and courses to cram for the bar exam. For students who must accept low-paid fellowships after graduation simply to stay in the running for a permanent job, the expenses mount still further.

These costs saddle a majority of law school graduates with crushing debt. As Professor Tamanaha documents, nearly ninety percent of law students graduated with debt in 2010; the average amount borrowed for law school approached $\$ 100,000 .^{35}$ Even that figure understates the extent of law student debt: it excludes college loans; bar-study loans; private loans for law school $;^{36}$ interest accrued during law school; ${ }^{37}$ and interest accrued during the six months after law school, when most graduates must devote their time to bar study and job seeking. ${ }^{38}$

rather than need; they also award scholarship aid very unevenly. A few students in each class may obtain a free ride, while others receive partial scholarships. At least some in each class, however, will pay the full--and ever rising-list price tuition.

32. See supra notes 4-5. Inflation has also been quite low in recent years. The average annual rate of inflation decreased $0.4 \%$ between 2008 and 2009; increased $1.6 \%$ from 2009 to 2010 ; increased $3.2 \%$ from 2010 to 2011 ; and increased 2.1\% from 2011 to 2012. Consumer Price Index: All Urban Consumers, U.S. DEP'T. OF LABOR, BUREAU OF LABOR STATISTICS, ftp://ftp.bls.gov/pub/special.requests/cpi/cpiai.txt (last visited Mar. 30, 2013).

33. For an excellent discussion of the opportunity costs, see Herwig Schlunk, Mamas 2011: Is a Law Degree a Good Investment Today?, 36 J. LEGAL PROF. 301 (2012).

34. American Bar Association Standards and Rules of Procedure for Approval of Law Schools § 304(f), available at http:/www.americanbar.org/content/dam/aba/publications/misc/legal_education/Standards/ chapter_3_2012_2013_aba_standards_and_rules.authcheckdam.pdf (last visited Mar. 16, 2013).

35. TAMANAHA, supra note 1 , at 120 .

36. Although most law students use federally funded loans to finance law school, some still use private bank loans. Private loans allow students to choose variable, rather than fixed, interest rates. In the current market, variable rates are much lower than the government's fixed rate; those rates are attractive to students who believe they will pay off their loans quickly. On March 30, 2013, for example, Discover Bank was offering a variable law school loan with a rate as low as 3.25\% APR. https:/www.discover.com/student-loans/private-student-loans/ law-school-loans.html.

37. Until recently, the federal government subsidized interest on the first $\$ 8,500$ of federally backed loans disbursed to law students each year; no interest accrued on that principal until after graduation. Interest did, however, accrue on federal loans above that amount. Since July 1, 2012, professional students no longer benefit from the interest subsidy; they accrue interest on the full amount of their federal loan from the day that the loan is disbursed. Recent Changes to the Student Aid Programs, U.S. DEP'T OF EDUC., OfFICE OF FED. STUDENT AID, http://studentaid.ed.gov/about/announcements/recent-changes (last visited Mar. 16, 2013).

38. Law school "debt" figures derive from information that the ABA gathers from all law schools. The annual questionnaire requests information only on "law school debt" that is "processed through the university or law school financial aid office." ABA 2011 Annual Questionnaire, Part 4, Financial Aid, at 1. Those instructions 
In addition to reflecting the length and expense of the guild's training path, this debt creates an independent barrier to guild-weakening competition. Law graduates burdened with heavy debt cannot easily challenge guild norms. Suppose a new lawyer has an innovative idea for creating a lower-priced practice, or one that serves a new client niche. How will the lawyer fund that venture? Banks will hesitate to lend money to unproven professionals who already bear significant debt, and the rules of "professional conduct" foreclose other options. Under the Model Rules of Professional Conduct, a lawyer cannot seek outside investors in her practice-or even partner with a non-lawyer. ${ }^{39}$ High debt significantly impedes the ability of new lawyers to finance practice models that might shake up the market.

Junior lawyers face other pressures to follow guild practices. During their early careers, most lawyers work directly for senior colleagues or seek referrals from them. Having invested heavily in their own training, these new lawyers hesitate to impair their advancement and lose the opportunity to share in guild profits. Heavy debt exacerbates these pressures, creating career risks for lawyers who challenge the status quo. Today's graduates, furthermore, will remain in debt for a substantial portion of their careers. As Professor Tamanaha reveals, many will not make their last loan repayments until after they have celebrated their twenty-fifth law school reunions. ${ }^{40} \mathrm{~A}$ quarter-century of nondischargeable debt erects a substantial barrier to innovation.

Through these avenues, the legal profession effectively deploys a long, difficult, and expensive training path to limit entry to the guild's most favored positions. Clarence Darrow recognized this mechanism early in the last century:

exclude private loans, which are not processed through those offices. Id. The instructions also expressly exclude "post J.D. loans (i.e. bar loans) even if distributed prior to graduation." Id. Finally, the questionnaire requests information on the "average amount borrowed in law school," not any accrued interest related to those amounts. Id. at 6. Law schools follow these instructions to the letter, reporting only these carefully circumscribed "amount[s] borrowed."

39. Model Rules of Prof'L Conduct R. 5.4 (2009). An ABA Commission recently refused to make even minor amendments to this rule. See Press Release, Am. Bar Ass'n, ABA Commission on Ethics 20/20 Will Not Propose Changes to ABA Policy Prohibiting Nonlawyer Ownership of Law Firms (Apr. 16, 2012) available at http://www.americanbar.org/content/dam/aba/administrative/ethics_2020/20120416_news_release_ re_nonlawyer_ownership_law_firms.authcheckdam.pdf.

40. TAMANAHA, supra note 1 , at 119. The 25-year period stems from the government's "Income Based Repayment" program, which extends the traditional 10-year repayment to as long as 25 years. As Professor Tamanaha carefully explains, graduates using this 25-year option will pay substantially more interest than lawyers who are able to repay their loans within 10 years. For some students, the loans will even suffer negative amortization under the 25-year plan. Id. at 121.

A new program, "Pay As You Earn," offers lower monthly payments than Income Based Repayment and forgives debt after 20 years. Pay As You Earn Plan, U.S. DEP'T of EdUC., OfFICE OF Fed. STUDENT Aid, http://studentaid.ed.gov/repay-loans/understand/plans/pay-as-you-earn (last visited Apr. 25 2013). This program, like Income Based Repayment, has both costs and benefits for debtors. 
The bar association of to-day lay down every conceivable condition; they require a longer preliminary study, and exact a college education and long courses in law schools, to keep new members out of the closed circle. The Lawyers' Union is about as anxious to encourage competition as the Plumbers' Union is, or the United States Steel Co., or the American Medical Association. $^{41}$

The mechanics for restricting guild entry are the same today as they were when Darrow wrote, except that the path has become even longer, more strenuous, and more expensive. ${ }^{42}$

\section{B. INTRAMURAL TOURNAMENTS}

The legal profession also relies upon intramural tournaments to restrict entry to the most remunerative positions in the guild. The first stage of competition occurs with law school admission. Schools vary enormously in their ability to provide lucrative and desirable jobs for their graduates; applicants understand this fact. ${ }^{43}$ Prospective lawyers carefully weigh the competitive advantage that various schools will give them in the marketplace. They also recognize the rules of the admissions contest, particularly the importance of high LSAT scores. Applicants who do not win sufficiently attractive admissions offers will invest in additional test-prep courses, retake the test, and hope for a better outcome in the next admissions cycle. From the very start, lawyer-hopefuls fight an intensely competitive battle.

Competition mounts during the first year of law school, when most schools enforce strict grading curves. The top ten percent of every class will enjoy opportunities largely inaccessible to the other ninety percent. The top students are more likely to receive invitations to the flagship law review, to obtain jobs through on-campus interviewing, and to secure the best jobs available to graduates of their school. As Professor Tamanaha recounts, students "speak

41. Clarence Darrow, The Story of My Life 29 (1932).

42. See Shepherd, supra note 12, at 451 (noting that lawyers benefit from the current system of legal education, including the expensive benefits demanded by faculty members, because "[w]hen faculty help themselves by increasing the price of legal education, by limiting the number of law schools, and by limiting student-faculty ratios, their efforts benefit existing lawyers by reducing the number of new lawyers").

We focus in this essay primarily on the role of law schools within this entry path. Law firms and other legal employers, however, also contribute to the path's length and expense. The period of "associateship," for example, is one in which a new lawyer both hones his skills and contributes to the partner's profits. The usual financial arrangement pays associates less than the revenue they generate; the excess rewards the partner for the training and client access she offers the associate. This arrangement is remarkably similar to one that many medieval craft guilds employed.

43. For a window into applicants' awareness, skim the entries in any of the forums at Top-Law-Schools.com, TLS Forums, TOP-LAw-SCHOOLs.COM, http://www.top-law-schools.com/forums/index.php. Commenters on that site meticulously analyze their career prospects at different law schools. 
enviously of [these] classmates who won the "lottery.",44 After just one year of law school, the profession has already sorted likely winners from losers.

The race continues throughout law school, with upper-level grades, moot court honors, and leadership positions on law reviews. ${ }^{45}$ At the same time, students compete to secure advantageous externships, summer positions, and part-time jobs. Students who lost the first-year lottery can recoup some competitive standing through these efforts. Law school grades alone, however, remain a major factor in predicting future success. ${ }^{46}$ The profession does not have places for every graduate; the results of these intramural competitions help determine which graduates will obtain law-related jobs. ${ }^{47}$

After law school, graduates face a key competition: the bar exam. Without bar passage, a graduate cannot practice law. State supreme courts and bar associations keep an eye on bar passage rates; if the percentage rises too high, they toughen the exam. ${ }^{48}$ As a result, the bar exam is a competitive exercise-pitting applicants against one another-rather than a stable measure of ability that all qualified applicants will surmount.

In the workplace itself, the battle continues. Some organizations have room for all attorneys to advance, but many do not. The competition is particularly fierce at the largest law firms, where the access to monopoly profits is most likely. Several scholars have written about the "tournament style" of employment at these firms. ${ }^{49}$ Of the dozens of lawyers hired initially by these firms, only a select few become partners. Indeed, an increasing number of firms have added new

44. TAMANAhA, supra note 1, at x. Cf. Posner, supra note 16 , at 14 (noting the competition for success among earlier generations of English barristers and the fate of "those who lost out in the barrister lottery").

45. More than thirty years ago, one of the first author's law school classmates observed: "The summer after our first year, I thought law school was an institution designed to make $90 \%$ of the class unhappy. Now that the law review board of editors has been announced, I understand that it is an institution designed to make all but one person unhappy." A few weeks later, a different classmate complained about the process for seeking judicial clerkships. "I don't understand why it takes the judges so long to select clerks," he opined. "There's a recognized hierarchy of judges and a recognized hierarchy of law students. It shouldn't be so hard to match them up." Today's law students offer similarly cynical observations about hierarchy in the legal profession.

46. See Richard Sander \& Jane Yakowitz Bambauer, The Secret of My Success: How Status, Eliteness, and School Performance Shape Legal Careers, 9 J. EMPIRICAL LEGAL STuD. 893, 895 (demonstrating the strong influence of law school performance on career outcomes).

47. Nine months after graduation, just $56.0 \%$ of the class of 2011 reported holding jobs that required bar admission. See NALP Bulletin, supra note 5. Students at high-ranked schools are more likely to obtain these jobs than students at lower-ranked ones, TAMANAHA, supra note 1, at 117. Notably, however, some graduates at every school obtain jobs-while some at every school fail to do so. This pattern reflects the series of ongoing tournaments that mark legal education.

48. Courts and bar associations commonly describe this practice as a desire to keep their passing rates at or below rates in other states; they do not want their bar exam to seem too "easy" compared to the exams in other states. See generally Merritt et al., supra note 29, at 939.

49. See, e.g., Marc Galanter \& Thomas Palay, Tournament of Lawyers: The Transformation of the Big LAW FIRM (1991); Marc S. Galanter \& Thomas M. Palay, Large Law Firm Misery: It's the Tournament, Not the Money, 52 VAND. L. REv. 953 (1999); David B. Wilkins \& G. Mitu Gulati, Reconceiving the Tournament of Lawyers: Tracking, Seeding, and Information Control in the Internal Labor Markets of Elite Law Firms, 84 VA. L. REv. 1581 (1998). 
levels of tournament play by creating several tiers of partners.

These intramural competitions offer few benefits to clients. The contests do little to lower prices; indeed, many law firm associates secure advancement by billing high hours to clients. Intramural competitions, furthermore, waste client and firm investments by discarding skilled lawyers when there is insufficient room at the top. Nor do the tournaments necessarily select the highest quality lawyers from a client's perspective. Associates win promotion by pleasing partners; they have little opportunity to develop innovative business structures that clients might favor.

Law schools, meanwhile, are far removed from client demands. Schools have some incentive to produce lawyers who will succeed in the guild; that brings both reputational acclaim and alumni donations to the school. But the link is attenuated, and schools rarely see firsthand what types of education might benefit clients. The organizations that control the first key levels of guild competition, therefore, know little about client needs. The competitions that law schools create, for both entry and internal success, may not produce the lawyers who would serve clients best.

For lawyers, the series of intramural competitions serves many purposes. The contests help identify the aspirants who are willing to dedicate themselves to the guild, serving long hours in training or subordinate positions. The tournaments also provide some information about a lawyer's ability and responsiveness to clients. Most important for guild members, the competitions limit the number of lawyers who share the guild's greatest profits-while maintaining the appearance of an open profession determined to identify the "best" players to serve clients. ${ }^{50}$

\section{THE COST OF RESTRAINTS}

What are the costs of the guild system described above? Most guilds, however they are maintained, cost the consumer money. ${ }^{51}$ Several economists, using a variety of approaches, have demonstrated empirically that the United States legal profession does reap excess profits from its guild status. ${ }^{52}$ These unearned rents burden individual consumers and the collective economy. Equally worrisome in the current era of economic change and global competition is the fact that

50. Cf. Posner, supra note 16, at 14 (noting the competition for success among earlier generations of English barristers).

51. FRIEDMAN, supra note 22, at 148 ("[Licensure] almost inevitably becomes a tool in the hands of a special producer group to obtain a monopoly position at the expense of the rest of the public."); CLIFFORD WINSTON, ET AL., FIRST Thing We Do, LeT's DeRegulate All THE LAWYERS 96 (2011) ("[E]conomic theory provides strong a priori reasons .... to expect that lawyers [benefiting from entry restraints] may earn premiums that are attributable to market inefficiencies.").

52. WINSTON, ET. AL., supra note 51, at 16-18, 21-28 (summarizing studies); Mario Pagliero, What Is the Objective of Professional Licensing? Evidence from the US Market for Lawyers, 29 INT'L J. INDUS. ORG. 473, 481 (2011); Mario Pagliero, Licensing Exam Difficulty and Entry Salaries in the US Market for Lawyers, 48 BRIT. J. Indus. REL. 726, 736-37 (2010). 
professional barriers to entry hamper innovation in law practice. ${ }^{53}$ Guild lawyers have little incentive to devise cheaper, more responsive methods of delivering client services. Indeed, the heavy debt borne by new lawyers encourages them to follow guild practices in the hope of eventually achieving the promised pay-off.

In addition to these significant losses, Professor Tamanaha's work plainly demonstrates the costs of the current guild system for aspiring lawyers. By maintaining a system that invites a large number of entrants; extracts substantial investments of time and money from those applicants; and then ruthlessly winnows winners from losers, law schools and practitioners sustain a cartel that handsomely rewards its most established members. At the same time, the system imposes heartbreaking costs on the aspirants. Too many law students start with a dream of practicing a professionally rewarding and financially secure job-but end with a nightmare of debt and limited employment opportunities.

These costs have grown too large to countenance. As Professor Tamanaha recognizes, "[l]aw school has always had winners and losers in job prospects among graduates." 54 The profession, in other words, has always used intramural contests to restrict access to the highest guild levels. Similarly, for at least the last century, the profession has maintained long and expensive entry paths for prospective lawyers. "The difference today," as Professor Tamanaha writes, "is that the enormous run up in tuition of the last three decades, and the student debt this produces, imposes a severe penalty on losers that did not exist in past generations." 55 Both our profession and the larger society must confront the implications of that severe penalty. ${ }^{56}$

53. See, e.g., WINSTON, ET. AL,, supra note 51, at 73-75; Gillian K. Hadfield, Legal Barriers to Innovation: The Growing Economic Cost of Professional Control Over Corporate Legal Markets, 60 STAN. L. REv. 1689, 1709-28 (2008); Gillian K. Hadfield, Higher Demand, Lower Supply? A Comparative Assessment of the Legal Resource Landscape for Ordinary Americans, 37 FORDHAM URB. L.J. 129, 155 (2010); Larty E. Ribstein, The Death of Big Law, 2010 WIs. L. Rev. 749, 803 (2010); Shepherd, supra note 12, at 460 (legal profession's trade barriers push lawyers to offer only high-priced services rather than designing "cheaper but serviceable" products).

54. TAMANAHA, supra note 1 , at $\mathrm{x}$.

55. Id.

56. In an earlier essay, we set out the responsibilities that professionals assume in return for restraints of trade. See Deborah J. Merritt \& Daniel C. Merritt, Responsibility-Rights in the Legal Profession, 43 ARIZ. ST. L.J. 1257 (2011). If practitioners and legal educators honored those responsibilities, potential lawyers would not confront the severe penalties they face today; the profession would establish more reasonable training paths. See also Paul Horwitz, What Ails the Law Schools?, 111 MICH. L. Rev. 6 (2013) (urging law schools to exercise their responsibilities in a way that better addresses client needs). As we acknowledged in our earlier essay, however, responsibility-rights run counter to human nature. Law schools, like other organizations, do not always fulfill their highest responsibilities. Indeed, recent evidence suggests that schools have engaged in a surprising amount of deceptive and unethical behavior. See generally Ben Trachtenberg, Law School Marketing and Legal Ethics, 91 NEB. L. REV. (forthcoming June 2013) (describing a wide range of ethical violations in law school marketing). When a profession cannot match responsibilities to rights, competition provides a better solution. Merritt \& Merritt, supra, at 1269-71. 


\section{The CASE FOR the MARKET}

There is only one sure way to eliminate the penalties identified by Professor Tamanaha: deregulate the legal profession by abolishing prohibitions against the unauthorized practice of law. As long as lawyers maintain their professional walls, sharply dividing those who are "authorized" to practice law from all others, they will charge high prices to potential entrants. Where there are walls, there are gatekeepers. Where there are gatekeepers, there are opportunities to extract excess tolls. ${ }^{57}$

Imagine, for example, that the legal profession adopted one of Professor Tamanaha's recommendations: "two years of book learning followed by a oneyear apprenticeship." 58 This is a plausible proposal; it might achieve the optimal mix between classroom instruction and hands-on training. But there is no reason to believe that this route would be cheaper for aspiring lawyers. The same economic factors that allow law schools to charge excessive tuition for three years of instruction will allow them to set high rates for a two-year degree. ${ }^{59}$ The practitioners who offer apprenticeships, meanwhile, will acquire their own gatekeeper power; they may turn apprenticeships into training programs with fees of their own. Prospective lawyers may start borrowing to fund both law school and post-graduate training. ${ }^{60}$

Capping government loan programs might rein in these costs, but it would not eliminate excessively high fees for people seeking to enter the legal profession. The root problem lies in the trade restraints surrounding the profession itself. Those restraints both allow the profession to restrict entry and give it a strong motive to do so. Lawyers do not sell bar admissions in the same way that New York City sells taxi medallions; we do not coin a limited number of seats

57. See WINSTON, ET AL., supra note 51, at 90-91 (observing that high law school tuition "in part reflect[s] the future premiums to be earned by lawyers," and suggesting that deregulation of the profession would lower costs of training); Shepherd, supra note 12, at 452 (describing the professional "bottleneck" enjoyed by accredited law schools, which "gives virtually complete control not only over the market for faculty, but also over the downstream markets for legal training and legal services").

58. TAMANAHA, supra note 1 , at 173.

59. Northwestern Law School made headlines when it offered an accelerated JD program, allowing participants to earn the degree in two calendar years. The school, however, "prices tuition by the degree pursued rather than the length of enrollment." Northwestern Law, Tuition and Financial Aid, http://www.law.north western.edu/academics/ajd/tuition_financialaid.html (last visited Mar. 16, 2013). Two-year students, therefore, pay the same total tuition as those who pursue the conventional three-year program. Id.

60. Competition in both the classroom and apprenticeship markets might curtail some of these prices. Schools might compete with scholarships to attract the most credentialed students to two-year programs, just as they currently compete to admit those students to three-year programs. Law firms, similarly, might compete for the best apprentices by offering higher wages. The track record within legal education, however, suggests that this competition would be limited. Over time, the cost of attending law school has risen dramatically, despite some competition for the best students. The barriers to professional entry, we assert, are a major cause of those price increases. Leaving those barriers in place is likely to push up prices for any type of educational or training path. 
and sell them to the highest bidders. ${ }^{61}$ Instead, the profession uses the requirement of bar admission to fashion a long, strenuous, and expensive entry path marked by a series of harsh intramural competitions. Law schools profit from that system, but so do established members of the profession. We can tweak the path's features, but the heavy costs for professional aspirants won't disappear unless the underlying restraints dissolve.

There is another, equally imperative reason to fix legal education by eliminating the inefficient restraints underlying the profession. Our profession has entered a time of profound change, in which technology, global competition, and commoditization are reshaping the delivery of legal services. ${ }^{62}$ Direct market forces offer the best hope of matching professional preparation to clients' rapidly changing demands. Law schools, accrediting agencies, and bar admission authorities all operate within their own bubbles. As long as schools are preparing graduates for guild admission, rather than directly to serve clients, they will not respond efficiently to client needs.

We agree with Professor Tamanaha that loosening accreditation standards would allow law schools to innovate; differentiating their programs to compete for applicants. But the ingenuity of law faculty is limited. They may recognize the demand for a "Holiday Inn-type law school" to supplement more luxurious modes. ${ }^{63}$ Faculty, however, are less likely to recognize that clients want an entirely different service, such as campgrounds or bowling alleys. Open markets are the most efficient way to channel information from consumers to producers.

What would this open market look like? It would operate under the same rules that regulate other business markets in the United States; clients would benefit from a large number of consumer-protection and anti-fraud laws. Clients, however, could hire any individual or organization they chose to perform their legal work. Many clients would still choose experienced practitioners with JDs for their work. Others would find that a paralegal, college graduate who had majored in law, or professional with one year of "law school" could do the job. Some client needs would require customized services, while others would benefit from standardized forms or interactive websites.

At an earlier time, clients might have lacked sufficient information to choose among these services. But in today's information age, clients have resources to assess skill and trustworthiness. Service providers have strong incentives to build

61. For a recent description of the market for taxi medallions, see Dan Cumming, Why Has the Price of Taxi Medallions Increased So Dramatically? An Analysis of the Taxi Medallion Market, 17 ThE PARK PLACE ECONOMIST 12 (2009), available at http://digitalcommons.iwu.edu/parkplace/vol17/iss1/9 (last visited Mar. 16, 2013).

62. For a leading discussion of these changes, see RICHARD SussKIND, THE END OF LAWYERS? RETHINKING THE NATURE of Legal Services (rev. ed. 2010); see also William D. Henderson, Three Generations of U.S. Lawyers: Generalists, Specialists, Project Managers, 70 MD. L. Rev. 1 (2011) (discussing these market changes in the context of legal education), available at http://papers.ssrn.com/sol3/papers.cfm?abstract_id=1809866.

63. TAMANAHA, supra note 1 , at 174 . 
their reputations and provide information about their skills-especially when those providers can no longer rely upon guild protection. Prospective clients would gain access, not only to new types of legal services, but to a wide range of information about those services. Bar associations, consumer groups, and client organizations could supplement that information by certifying lawyers who met particular performance standards. ${ }^{64}$ Those certificates would carry more nuanced information than the blunt signal of bar admission. Courts could also toughen malpractice standards for lawyers, aligning them with standards imposed on doctors. ${ }^{65}$

In a few contexts, poor professional performance imposes negative externalities on third parties. An incompetent trial lawyer, for example, wastes the time of the court, the jury, opposing counsel, and any adverse parties. Similar externalities may occur in administrative hearings and other procedures that involve multiple parties. Courts and other adjudicators could address this problem by requiring counsel to demonstrate competence before appearing in the forum. These competency requirements might be as rigorous as current bar examinations, although they would focus on skill sets most relevant to the forum. A federal district court, for example, might test prospective counsel more rigorously on the Federal Rules of Civil Procedure than on the rule against perpetuities. $^{66}$

Law schools would find many opportunities to sell their services in this market. Some might specialize in producing lawyers who practice in court. Others might tailor their education for transactional lawyers, eliminating expensive litigation training. Still others would continue to offer the traditional "fully rounded" JD. Colleges might begin offering degrees tailored to certain

64. See Winston, ET AL., supra note 53 , at 87 (citing examples of current certification schemes); id. at 83 (noting that states could even continue offering bar exams as a quality measure, publishing results to potential clients); Adam B. Summers, Licensing Lawyers: Failure in the Provision of Legal Services, in ThE PURSUIT OF JustiCE: LAW AND ECONOMICS OF LEGAL InSTITUTIONS 235, 250-53 (Edward J. López ed. 2010) (noting current and potential certification schemes for legal practitioners). Since any organization could provide certification, bar associations would not be able to capture that process to continue the profession's guild status. Experience in other fields suggests that a range of consumer and professional associations would offer certification services.

65. See Benjamin H. Barton, Do Judges Systematically Favor the Interests of the Legal Profession?, 59 ALA. L. REv. 453, 491-502 (2008) (documenting that current rules treat lawyers more leniently than doctors).

66. The Multistate Bar Exam (MBE) does not currently test knowledge of the Federal Rules of Civil Procedure, although the examiners will add the subject in February 2015. See Gulp! Civil Procedure will be added to Multistate Bar Exam, ABA JouRNAL (Mar. 8, 2013, 10:07 AM), http://www.abajournal.com/news/ article/gulp_civil_procedure_will_be_added_to_multistate_bar_exam/. The MBE does require knowledge of the rule against perpetuities. See National Conference of Bar Examiners, Subject Matter Outlines, http:// www.ncbex.org/assets/media_files/Information-Booklets/SMOs-from-MBEIB2012.pdf (last visited Mar. 16, 2013).

In an open system, different courts might adopt different exams; this could impose burdens on attorneys appearing before several courts. That burden, however, is no greater than the one attorneys currently face when they practice in more than one state. Indeed, exams qualifying lawyers for court practice probably would cover fewer subjects than the general bar exams that states currently administer. 
types of legal work. Community colleges could expand their paralegal programs. Part-time and online programs might proliferate as practitioners moved from one level of expertise to another. The market would generate approaches that we can't even imagine-approaches that are unlikely to originate from the crabbed creativity of law faculties preparing students for a unitary profession.

We conclude by addressing two concerns frequently voiced about deregulation. First, will deregulation allow untrained, unscrupulous hacks to prey upon unsuspecting consumers? Of course it will, but no more so than the current system of regulation. Scholars have repeatedly complained that courts and bar committees do a poor job of disciplining incompetent or dishonest lawyers. ${ }^{67}$ Disciplinary authorities are reluctant to penalize colleagues within their own guild; judges, similarly, resist malpractice actions against fellow lawyers. ${ }^{68}$ An open market for legal services would not abandon all regulation; it would replace self-interested guild regulation with all of the anti-fraud and consumer protection laws available in our legal system. ${ }^{69}$

Deregulation might, in fact, increase the quality of legal work. A few empirical studies suggest that, at least in some law-related fields, non-lawyers provide better services than lawyers-not just cheaper service, but higher quality service. ${ }^{70}$ United States consumers are already voting with their feet on that issue, hiring non-lawyers for a wide range of legal work when they cannot afford guild prices. ${ }^{71}$ Rather than relegating that market to the shadows, or attempting to suppress these initiatives, our society could benefit consumers by embracing the full scope of providers who can offer law-related assistance.

Finally, how will we provide legal services to the poor? Without the ideals of a protected profession, will any lawyers step forward to offer pro bono legal assistance? The answer to this question, sadly, is straightforward: despite more

67. See Arthur F. Greenbaum, The Automatic Reporting of Lawyer Misconduct to Disciplinary Authorities: Filling the Reporting Gap, 73 OHIо ST. L.J. 437, 439-42 (2012); Jack A. Guttenberg, The Ohio Attorney Disciplinary Process-1982 to 1991: An Empirical Study, Critique, and Recommendations for Change, 62 U. Cin. L. Rev. 947 (1994); Geoffrey C. Hazard, Jr. \& Dana A. Remus, Advocacy Revalued, 159 U. PA. L. Rev. 751, 772-77 (2011); Judith L. Maute, Bar Associations, Self Regulation and Consumer Protection: Whither Thou Goest? 2008 J. Prof. LAW. 53.

68. Barton, supra note 65, at 465, $491-503$ (2008); Deborah L. Rhode, The Profession and the Public Interest, 54 Stan. L. REv. 1501, 1512-14 (2002).

69. Many years ago, Milton Friedman addressed the "consumer protection" rationale for professional regulation by noting that members of the public rarely push for protection; instead, "the pressure invariably comes from members of the occupation itself." FRIEDMAN, supra note 22, at 140. Friedman continued wryly that "[o]f course, [the members of the profession] are more aware than others of how much they exploit the customer and so perhaps they can lay claim to expert knowledge." Id.

70. See, e.g., Herbert M. Kritzer, Legal Advocacy (1999); Richard Moorhead et al., Contesting Professionalism: Legal Aid and Nonlawyers in England and Wales, 37 LAW \& Soc'Y Rev. 765 (2003); see also Summers, supra note 64 , at 238-40 (listing factors that diminish quality in regulated professions).

71. See, e.g., TAMANAHA, supra note 1, at 170 (noting the rise of online legal services, as well as “'immigration assistance' or 'divorce assistance' services that help people fill out and file the necessary documents at low rates"). 
than a century of economic protectionism, the American legal profession has never given low and middle-class Americans the affordable legal services they need. Indeed, the problem has grown worse with time. ${ }^{72}$ Numerous observers, from both law and economics, have concluded that poor and middle-income Americans would obtain better legal assistance if the legal profession were deregulated. ${ }^{73}$ Trade restrictions have not served the poor; an open market holds the promise of doing so.

Deregulation will impose few costs while generating many benefits. Consumers will benefit from cheaper, more responsive services. Society will derive positive externalities from the efficient resolution of legal claims. Perhaps most important for purposes of this essay, lawyers will benefit. Our guild's system for restricting entry is destroying the lives of too many lawyers. The profession's intramural tournaments have long tormented students and practitioners, contributing to high rates of mental illness and substance abuse. ${ }^{74}$ To maintain its profits, the guild must drive some lawyers out of the profession - an outcome that wastes training and produces personal heartbreak.

Long, expensive entry paths have compounded the harm. As Professor Tamanaha so ably documents, these expenses have escalated to the point of cruelty. Aspiring attorneys can no longer learn to think like a lawyer, practice their skills, and count on finding a job that will pay off their educational expenses. Today, law school leads too many of them to high debt and low employment. We are responsible, as both educators and practitioners, for the harm this system is causing. Dismantling the walls that protect the lawyer guild is the surest way to eliminate these destructive paths to entry.

\section{CONCLUSION}

Professor Tamanaha has written a book that is both grounded and far-reaching. Failing Law Schools offers a wealth of sound data and creative proposals; these have already stimulated discussions in faculty lounges and bar offices across the

72. See Legal Services Corp., Documenting the Justice Gap In America: The Current Unmet Civil Legal NeEDS OF LOW-INCOME AMERICANS (2009), available at http://www.lsc.gov/pdfs/documenting_the_ justice_gap_in_america_2009.pdf; DAVID LUBAN, LAWYERS AND JUSTICE: AN ETHICAL STUDY (1988); DEBORAH L. RHODE, ACCEss To Justice (2004); Hadfield, Higher Demand, supra note 53, at 130. High levels of professional debt may contribute further to lawyers' reluctance to offer pro bono services. See Shepherd, supra note 12 , at 461 .

73. See, e.g., WINSTON, ET AL., supra note 51, at 91-93; Denise R. Johnson, The Legal Needs of the Poor as a Starting Point for Systemic Reform, 17 YALE L. \& POL'y REV. 479 (1998); Summers, supra note 64, at 244-45. Cf. Roger C. Cramton, Delivery of Legal Services to Ordinary Americans, 44 CASE W. RES. L. REv. 531, 615 (1994) (advocating greater service to the poor and middle classes by "limit[ing] the professional monopoly to its historic core-the representation of clients before courts of general jurisdiction").

74. See Laura Rothstein, Law Students and Lawyers with Mental Health and Substance Abuse Problems: Protecting the Public and the Individual, 69 U. PITT. L. REv. 531 (2008) (citing sources documenting these problems in the legal profession and discussing remedies). 
country. As policy makers confront the problems identified by Professor Tamanaha, they will turn repeatedly to his book for guidance. Equally important, the book offers a platform for further professional reflection: what are the goals of our profession? How do law schools contribute to those aims? Do our training paths offer the best results for lawyers and their clients? Pursuing those questions, as we have tried to do here, reveals deep cracks in our profession's foundation. We do not know whether Professor Tamanaha would agree with our particular analysis; we have built on his insights in our own way. But that is the greatest gift of Professor Tamanaha's book: it will prompt ongoing exploration of the challenges facing our profession and the remedies for those ills. 
